\title{
Establishment of Brachiaria brizantha cv. Marandu, under levels of soil water availability in stages of growth of the plants
}

\section{Leandro Coelho de Araujoㄹ, Patrícia Menezes Santos², Fernando Campos Mendonça², Gerson Barreto Mourão ${ }^{1}$}

\footnotetext{
${ }^{1}$ Escola Superior de Agricultura Luiz de Queiroz - ESALQ/USP - Departamento de Zootecnia, Piracicaba, SP, Brasil.

${ }^{2}$ Embrapa Pecuária Sudeste, São Carlos, SP, Brasil.
}

ABSTRACT - The objective of this work was to evaluate yield traits and development of palisadegrass under the influence of water deficit during the establishment period. The experiment was carried out in a greenhouse, in a completely random block statistical design in a factorial arrangement and additional treatment $(3 \times 3+1)$. The treatments referred to the suppression of irrigation at different phases of the establishment (sowing, germination and initial tillerring) until the soil presented water content of $75 \%, 50 \%$, and $25 \%$ of the moisture related to field capacity (qFC), besides control treatment with no water restriction. Evaluations of number of grown tillers per vase, green leaves per tiller and plant height were carried out weekly, for five weeks after the first tillers appeared. Biomass sampling was carried out approximately 30 days after the end of the last applied treatment, when the soil was kept close to $100 \%$ of field capacity relative moisture. Tillering and biomass yield of palisadegrass during establishment phase are reduced when water deficit is sufficient to make soil content water reach $25 \%$ of relative moisture field capacity, regardless to the season when water shortage takes place.

Key Words: biomass, drought, palisadegrass, tillering, water deficit

\section{Introduction}

The correct choice of the forage plant to form the pasture is the first step for the success of its exploration inasmuch as it improves support capacity, animal performance and productivity, and perennial pasture (Gomide \& Gomide, 2007). Brachiaria species have been used more in the establishment, formation and recovery of the pastures in Brazil (Zimmer \& Euclides, 2000).

All the plants are exposed to the stress conditions, represented by environmental biotic or abiotic factors, such as insects attack, competition with weeds, animal grazing, temperature variation, photoperiod or drought.

Water stress occurs when the transpiration rate of the plant exceeds its water absorption rate (Berkowitz, 1998) and each species can respond in a different way at the same water availability condition.

Lack of water in the soil interferes in the water relationships, in the physiology and morphology of the forage plants. According to its magnitude, this deficiency causes a stress, which can limit the forage production severely and even the survival of the species (Mattos et al., 2005b).

Pasture areas which are exposed to dry spell or seasonal drought are common in the whole country. However, there are few studies on the features which grant adaptations of the forage grass to the drought and the implications of this event in its development and perennial. Besides, in most part of the performed studies, plants already established were used and the effect of the water restriction in the grass establishment phases was not evaluated (Guenni et al., 2002; Mattos et al., 2005a).

The objective of this work was to evaluate the productive features and the Brachiaria brizantha (A. Rich). Stapf development cv. Marandu (palisadegrass) under water deficit influence on different phases of the initial establishment of the plants.

\section{Material and Methods}

The trial was performed at Embrapa Pecuária Sudeste ( $21^{\circ} 57^{\prime} 42^{\prime \prime}$ S, 47 $50^{\circ}$ '28"W and 860 m altitude) from January $16^{\text {th }}$ to March $10^{\text {th }}, 2007$. The average values \pm standarddeviation regarding the maximum, minimum temperature and the air average during the experimental period were $40.7 \pm 2.3 ; 19.8 \pm 1.5$ and $30.3 \pm 1.3^{\circ} \mathrm{C}$ respectively.

The used soil is classified as Oxisol (US, 1999) and it collected (December $1^{\text {st }}, 2006$ ) from $0.20 \mathrm{~m}$ depth and it was sifted afterwards ( $4 \mathrm{~mm}$ ). After the soil was dried in the open air, a sample was collected for physical and chemical analysis, in which the sand, clay and silt levels were determined, 
corresponding to $38.7 ; 44.4$ and $16.9 \%$ respectively and the following chemical composition values: $\mathrm{pH} \mathrm{CaCl}_{2}$ and $\mathrm{H}_{2} \mathrm{O}=5.0 ;$ P-resin $=6.0 \mathrm{mg} / \mathrm{dm}^{3} ; \mathrm{K}=0.11 ; \mathrm{Al}^{3^{+}}=0.1$; $\mathrm{Ca}^{2+}=2.4$ and $\mathrm{Mg}^{2+}=0.8 \mathrm{cmol}_{\mathrm{C}} / \mathrm{dm}^{3}$.

The plants were grown in plastic vases, each one of them with $9.0 \mathrm{~kg}$ of dry soil (January $\left.15^{\text {th }}, 2007\right)$ and fertilized afterwards (Malavolta, 1980) with $0.228 \mathrm{~g} / \mathrm{dm}^{3} \mathrm{P}_{2} \mathrm{O}_{5}$; $0.120 \mathrm{~g} / \mathrm{dm}^{3} \mathrm{~K}_{2} \mathrm{O} ; 11.111 \mathrm{~g} / \mathrm{dm}^{3} \mathrm{~N} ; 0.555 \mathrm{mg} / \mathrm{dm}^{3} \mathrm{~B} ; 0.166 \mathrm{mg} / \mathrm{dm}^{3}$ $\mathrm{Cu} ; 0.555 \mathrm{mg} / \mathrm{dm}^{3} \mathrm{Fe}$ and $0.166 \mathrm{mg} / \mathrm{dm}^{3} \mathrm{Mn}$, in the MonoAmonio-Fosfato manner, potassium chloride, ammonium sulfate, boric acid, copper sulphate, phosfate ammonium ferrous and manganese sulfate, respectively.

The vases were irrigated (January $16^{\text {th }}$, 2007) until the soil could reach the humidity corresponding to the field capacity (qFC), which was previously determined by the gravimetric method. After it, 15 seeds were put in a $1 \mathrm{~cm}$ depth vase.

When the plants reached 4 expanded leaves, on average, all the vases were thinned, leaving just four plants per experimental unit.

The trial was conducted in a complete block design arranged in factorial arrangement $(3 \times 3)$ and additional treatment (control), with four repetitions, totaling 40 experimental units.

In the factorial arrangement, three conditions were evaluated for the beginning of the water shortage period, established according to the development phases of the plants in which the irrigation was ceased right after the sowing; $50 \%$ of the germinated seeds and $50 \%$ of the plants from the vases with at least one primary tiller, combined with three conditions for the final period of the water shortage which were defined based on the soil humidity in order to restart the irrigation (soil humidity next to 75; 50 and 25\% of the (qFC).

In order to make the understanding of the treatments easier, the denomination sowing, germination and tillering were used to characterize the factor which represents the respective development phases of the plants at the beginning of the water deficit, and 75qFC, $50 \mathrm{qFC}$ and 25 qFC to characterize the factor which represents the respective levels of water in the soil so that the irrigation is restarted. The combinations between the two factors were used to represent them (e.g. Sowing_75qFC) and were evaluated by comparing them to the control.

When the experimental units were not under water deficit the soil moisture was kept next to $100 \%$ of the qFC, as the one in the control treatment.

The soil moisture control was done in two phases. The first phase was at the beginning of the trial (January $16^{\text {th }}, 2007$ ) until the end of the last treatment (Tillering_25qFC; February $11^{\text {th }}$, 2007). During this phase, the vases of the control treatment $(n=4)$ were weighed daily and the amount of water to be added into them was determined by the difference between its current weight and the weight concerning the field capacity. The same quantity of water was added in the other vases which were not under water deficit (according to the block reference control).

During the same period (January $16^{\text {th }}$ to February $11^{\text {th }}$, 2007) the soil moisture of the vases under water deficit was controlled by their individual weighing every day in order to check the time to end the water deficit.

The second phase of the soil humidity control occurred at the end of the last treatment (Tillering_25qFC; February $\left.12^{\text {th }}, 2007\right)$ until the end of the experimental period (March 10 ${ }^{\text {th }}$, 2007). Due to the differences in the plants development during this phase, two vases of each treatment started to be used, located in different blocks, as moisture reference. The vases were weighted daily and the irrigation was done in order to supply the difference between the current weight of the vase and the weight concerning the field capacity.

During all the experimental period (January $16^{\text {th }}$ to March $10^{\text {th }}$, 2007) all the vases were weighed individually every seven days and sufficient amount of water was added into them, so the soil could return to the qFC in order to correct any mistake. The evaluated features correspond to the emerged tillers, the plants height, amount of live leaves and biomass yield.

Right after the beginning of the plants primary tillering, the amount of emerged tillers was counted in all the experimental units, with a seven day interval during the evaluations, totalling five evaluations.

The emerged tillers were identified with wire in order to avoid recount when tillers emerged in the next evaluations. All the tillers which could be identified by naked eye were included in the count.

Plant height was measured by using a millimeter ruler measuring the vertical distance from the soil in the vase to the curvature of the last expanded leaf. The measurements were performed together with the count of the emerged tillers.

The amount of the live leaves was counted along with the count of the emerged tillers. The leaf considered alive is the one with less than $50 \%$ of its area in senescence. The last expanded leaf was marked to make further counts easier.

The evaluations of the biomass yield and the quantity of the morphological fractions were done approximately 30 days after the end of the last applied treatment (Tillering_25qFC). The samplings were performed in two 
days (March $9^{\text {th }}$ and $\left.10^{\text {th }}, 2007\right)$, each day, the biomass was collected and the morphological separation of the plants present in two experimental blocks were done.

At this moment, all the vegetation in each vase was collected, at the soil level, separating morphologically in leaves (leaf blade), stems (stems + sheaths) and senescent matter (any tissue of the herbage mass with over $50 \%$ of senescence). After the root system recovery, it was washed in order to determine its dry matter. Total fraction of leaves, stems and senescent matter was denominated herbage mass.

Total yield of green leaves per vase was weighed and a sub-sample of approximately $30.0 \mathrm{~g}$ was packed in plastic bag and stored in refrigerator for further determination of the leaf area using the integrator of the leaf area, model LI-3100C (Li-cor, Lincoln, Nebraska, USA). Afterwards, the total leaf area was estimated per vase based on the total yield of leaves.

Leaf, stems, senescent tissue and root system were oven-dried $\left(65^{\circ} \mathrm{C}\right.$ for 72 hours) for DM analyses.

The collected data were submitted to the variance analysis through the SAS statistical program. The GLIMMIX procedure was used, in which the treatments were considered as fixed effects and the blocks and the interaction among them as random effects; for the variables measured in the time, evaluation system was also considered as fixed effects as well as the possible interactions, including, in this case, the covariance structure among such measurements.

For the variables resulting from the counts, Poisson's distribution was considered, using the logarithm connection function, and the methodology of generalized linear patterns (Nelder \& Wedderburn, 1972).

All the variables analyzed in this work presented residual variance homogeneity. The averages were compared by the Tukey test at the significance level of 5\%. The presented values are the adjusted averages obtained by the minimum square method. The average error-standard was adopted as dispersion measurement.

\section{Results and Discussion}

Effect of the water deficit on most of the yields varies according to its duration, intensity and occurrence period in the production cycle (Kramer,1995).

In this experiment, the water levels in the soil in order to restart the irrigation (end of the water deficit period) were very close to the values proposed to the referred study, from 2 to 19 days, according to the treatment (Table 1).

Tillering is an important process to assure the grass perennial inasmuch as the amount and the weight of a plant tillers determine its productivity (Nelson \& Zarrough, 1981). There were significant differences between the evaluations and plant development phase $(\mathrm{P}<0.0001)$, evaluations and water level in the soil $(\mathrm{P}<0.0001)$, besides the effect of interaction among the evaluations, water level in the soil and development phase of the plant $(\mathrm{P}<0.0001)$.

The triple expanding interaction $(\mathrm{P}<0.0001)$ demonstrated that only the plants submitted to the lowest level of the water in the soil had tillering affected at the beginning (weekly evaluation 1 and 2; Table 2).

By considering the development phases of the plants at the lowest level of water in the soil (Table 2), the treatments which had the irrigation interrupted in the sowing and at the beginning of the germination presented lower tillering rate during the first evaluation, with an average of less nine tillers than the other treatments (Table 2).

The evaluations of tiller count started as soon as $50 \%$ of the primary tillers emerged, in average, and from this moment, the supply of water for the tillering treatments was also interupted. Therefore, there was no reduction of the tillers amount which emerged during the first evaluation for these treatments, and the water deficit effect responded only in the next evaluation (evaluation 2; Table 2).

From the third evaluation, the differences in the amount of tiller emerged during the treatments were not observed (Table 2). Water deficit was sufficient to reduce the emergence of tillers during the drought, but it was not sufficient to affect the number of accumulated tillers, whose average was of 44 tillers/vase (Table 2) at the end of the trial, due to the emergence of new tillers when water supply was restarted.

For plant height, it was observed the effect of the water deficit introduction phase $(\mathrm{P}<0.0001$; Table 3$)$, evaluation $(\mathrm{P}<0.0001)$ and the interaction between the evaluation season and the water level in the soil $(\mathrm{P}<0.0019$; Table 4).

The plants presented behavior similar to the height during the five evaluations, regardless to the phase in which the water deficit was applied (Table 3).

The plant lowest height was observed in the most intense water shortage treatment (25qFC), until the fourth evaluation, and there were no differences among the plants at the last measurement, which had average height of $21.7 \mathrm{~cm}$ (Table 4).

The results obtained for the emerged tillers and the plant height made evident lower initial development of the palisadegrass when submitted to intense water deficit (25qFC; Tables 2 and 4); however, palisadegrass also demonstrated high recovery capacity of its structure after the water deficit period, making the compensating gain in 
Table 1 - Days when palisadegrass were kept under water deficit and soil moisture at the end of each treatment (2007)

\begin{tabular}{|c|c|c|c|c|c|c|c|c|c|}
\hline \multirow[t]{3}{*}{ Water deficit } & \multicolumn{9}{|c|}{ Treatment ${ }^{1}$} \\
\hline & \multicolumn{3}{|c|}{ Sowing } & \multicolumn{3}{|c|}{ Germination } & \multicolumn{3}{|c|}{ Tillering } \\
\hline & \multicolumn{3}{|c|}{ - qFC (\%) - } & \multicolumn{3}{|c|}{$-{ }_{-}$qFC (\%) - } & \multicolumn{3}{|c|}{ - qFC (\%) - } \\
\hline Beginning & $01 / 16$ & $01 / 16$ & $01 / 16$ & $01 / 21$ & $01 / 21$ & $01 / 21$ & $02 / 02$ & $02 / 02$ & $02 / 02$ \\
\hline End & $01 / 21$ & $01 / 26$ & $02 / 04$ & $01 / 25$ & $01 / 29$ & $02 / 05$ & $02 / 4$ & $02 / 6$ & $02 / 11$ \\
\hline Total & 5 & 10 & 19 & 4 & 8 & 15 & 2 & 4 & 9 \\
\hline
\end{tabular}

1 Treatments $=75 ; 50$ and $25 \%$ of the soil moisture related to the field capacity $(\mathrm{qFC})$ to restart the irrigation. Sowing, germination and tillering $=$ season of water deficit introduction.

Table 2 - Quantity of emerged palisadegrass tillers per vase in five weekly evaluations and accumulated total during the period

\begin{tabular}{|c|c|c|c|c|c|}
\hline \multicolumn{2}{|c|}{ Weekly evaluation } & \multicolumn{3}{|c|}{ Treatment $^{1}$} & \multirow[b]{2}{*}{ Tillering } \\
\hline & Control & & Sowing & Germination & \\
\hline & & \multicolumn{4}{|c|}{$-25 \mathrm{qFC}-$} \\
\hline & \multicolumn{5}{|c|}{ Amount of tillers/vase } \\
\hline 1 & $11(0.08) a$ & 2 & $(0.19) \mathrm{b}$ & $2(0.18) b$ & $11(0.08$ \\
\hline 2 & $13(0.0$ & 10 & $(0.10) \mathrm{a}$ & 7 (0.13)ab & $3(0.19$ \\
\hline 3 & $21(0.12) a$ & 22 & $(0.10) \mathrm{a}$ & $24(0.10) \mathrm{a}$ & $24(0.10)$ \\
\hline . & $1(0.63) a$ & 4 & $(0.26) \mathrm{a}$ & $2(0.41) a$ & $1(0.45)$ \\
\hline 5 & 1 (0.61)a & 1 & $(0.78) \mathrm{a}$ & 1 (0.55)a & $1(0.55) \mathrm{a}$ \\
\hline Accumulated & $47(0.05) \mathrm{a}$ & 40 & $(0.04) a$ & $37(0.05) \mathrm{a}$ & $42(0.04) a$ \\
\hline
\end{tabular}

${ }^{1}$ Treatments $=75 ; 50$ and $25 \%$ of the soil humidity related to the field capacity $(\mathrm{qFC})$ to restart the irrigation. Sowing, germination and tillering $=$ season of water deficit introduction.

Averages followed by the same letter in the line do not differ $(\mathrm{P}<0.05)$ by Tukey test. The average error-standard is presented in parenthesis.

its development sufficient enough so there was not distinction among the treatments in the last evaluations (Tables 2 and 4).

The amount of live leaves per tillers did not suffer changes concerning such treatments, there was no significant effect of the water availability $(\mathrm{P}=0.1824)$, regarding the development phase in which the water deficit was applied $(\mathrm{P}=0.5918)$. There were also no significant difference of water level $\times$ development phase $(\mathrm{P}=0.2013)$, water level $\times$ evaluation $(\mathrm{P}=0.1327)$, development phase $\times$ evaluation $(\mathrm{P}=0.4912)$ and water level $\times$ development phase $\times$ evaluation $(P=0.1929)$ interactions only in the seasons when the amount of live leaves were quantifiably influenced $(\mathrm{P}<0.001)$ in the variation of this feature (Figure 1).

Considering the quantity of live leaves and emerged tillers counted at the same time, it was expected that both structural features were influenced by the studied treatments, in a similar way, but, it was observed the quantity of live leaves in the main tiller is not a good parameter to characterize the water stress in palisadegrass during the establishment, and the emergence of tillers is more sensitive to the variations in the water level in the soil during this introduction phase of the pasture.

Cunha at al. (2007) did not observe effect of the irrigation levels in the quantity of live leaves per tiller in Panicum maximum cv. Tanzania when submitted to the regrowth periods in soil kept with different moisture levels (50; 75 and $100 \%$ of the total availability of water in the soil).

The effect observed in the quantity of live leaves due to the evaluations ( $\mathrm{P}<0.001$; Figure 1$)$ is similar to the one reported by Gomide \& Gomide (2000) for evaluations performed in the main tiller during the establishment period of yields of Panicum maximum Jacq.

The leaf area per vase was not influenced by the development phase ( $\mathrm{P}=0.634)$, by the level of the water in the soil $(\mathrm{P}=0.7237)$ and by their interaction $(\mathrm{P}=0.4484)$, presenting average value of $5662.4 \mathrm{~cm}^{2} /$ vase. This result is possibly caused by the restart period of the water supply provided to the plants after the water deficit, which was approximately 30 days, and it was also verified by Guenni et al; (2002) in Brachiaria ssp. plants after two sequential periods of water deficit followed by the restart of the water supply.

Among the evaluated morphological components, the production of dry matter of green leaves was the only variable influenced by the development phase in which the plants were submitted to the water deficit $(\mathrm{P}=0.0181)$, and the effect was more emphasized when the water deficit had started immediately after the palisadegrass sowing (Table 5).

The reduction of the water level in the soil affected negatively the final production of green leaves dry matter $(\mathrm{P}=0.0007)$, stems $(\mathrm{P}<0.0001)$, herbage mass $(\mathrm{P}<0.0001)$ and roots $(\mathrm{P}=0.0247)$ of the evaluated plants in this trial (Table 6), providing a reduction in these morphological components production of approximately $4.4 ; 18.8 ; 13.9$ and $15.7 \%$ respectively.

Similar result was observed by Melo et al. (2003), who reported a delay in the development of $B$. brizantha and 
Table 3 - Palisadegrass height in five weekly evaluations, according to the water deficit introduction phase

\begin{tabular}{|c|c|c|c|c|}
\hline \multirow[t]{2}{*}{ Weekly evaluation } & \multicolumn{4}{|c|}{ Water deficit introduction ${ }^{1}$} \\
\hline & Control & Sowing & Germination & Tillering \\
\hline \multicolumn{5}{|c|}{ Height $(\mathrm{cm})$} \\
\hline 2 & 16.5 (0.63)B & $15.2(0.37) \mathrm{C}$ & $15.5(0.38) \mathrm{C}$ & $15.0(0.38) \mathrm{C}$ \\
\hline 3 & $19.1(1.20) \mathrm{AB}$ & $18.0(0.71) \mathrm{AB}$ & $18.2(0.76) \mathrm{B}$ & $20.8(0.71) \mathrm{AB}$ \\
\hline 4 & $20.5(1.50) \mathrm{AB}$ & $20.0(0.88) \mathrm{AB}$ & $21.1(0.89) \mathrm{AB}$ & 20.7 (0.89)AB \\
\hline
\end{tabular}

Table 4 - Palisadegrass height in five weekly evaluations, according to the water level in the soil

\begin{tabular}{|c|c|c|c|c|c|c|}
\hline Weekly evaluation & \multicolumn{6}{|c|}{ Humidity of the soil ${ }^{1}$ (\%qFC) } \\
\hline \multicolumn{7}{|c|}{ Height (cm) } \\
\hline 2 & $16.5(0.63) \mathrm{Ba}$ & 17.4 & $(0.37) \mathrm{Ba}$ & $16.8(0.37) \mathrm{Ba}$ & 11.6 & $(0.37) \mathrm{Bb}$ \\
\hline 3 & 19.1 (1.20)Cab & 20.5 & $(0.73) \mathrm{Ca}$ & $20.7(0.72) \mathrm{Ca}$ & 15.8 & $(0.73) \mathrm{Cb}$ \\
\hline 4 & 20.5 (1.50)Dab & 22.0 & $(0.89) \mathrm{Da}$ & 22.7 (0.89)Da & 16.9 & $(0.89) \mathrm{Db}$ \\
\hline
\end{tabular}

${ }^{1}$ Moisture (\%) of the soil related to the field capacity (qFC) in order to restart the irrigation.

The control values (100\% qFC) represent the average of four repetitions. The treatments values $75 ; 50$ and $25 \mathrm{qFC}$ represent the average of three development stages and four repetitions. Averages followed by the same letter, capital letter in the column and lower-case in the line, do not differ $(\mathrm{P}<0.05)$ by Tukey test. The average error-standard is presented in parenthesis.

Table 5 - Leaf blade dry matter yield of palisadegrass according to the water deficit introduction phase

\begin{tabular}{lc}
\hline Water deficit introduction $^{1}$ & Leaf blade (g/vase) \\
\hline Control & $30.1(0.86) \mathrm{AB}$ \\
Sowing & $28.7(0.49) \mathrm{B}$ \\
Germination & $29.0(0.49) \mathrm{AB}$ \\
Tillering & $30.7(0.49) \mathrm{A}$ \\
\hline
\end{tabular}

${ }_{1}^{1}$ Sowing, germination and tillering $=$ season of the water deficit introduction. The values represent the average of four repetitions.

Averages followed by the same letter do not differ $(\mathrm{P}<0.05)$ by Tukey test.

The average error-standard is presented in parenthesis.

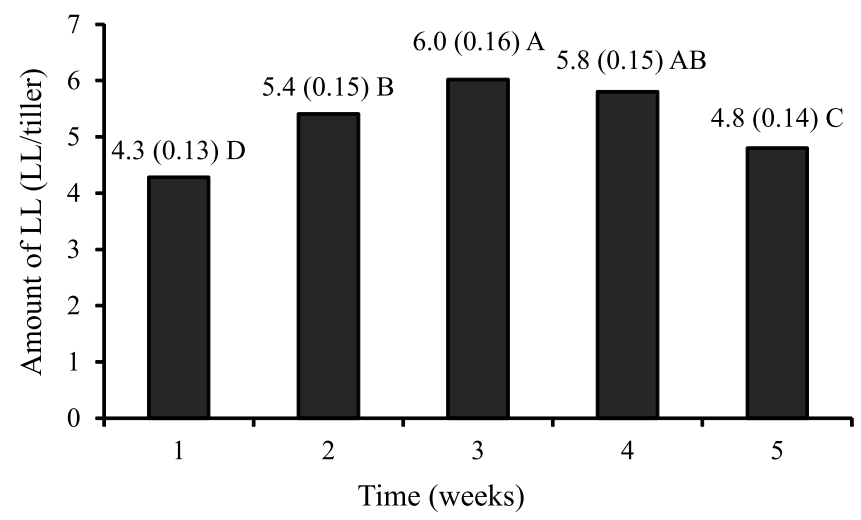

The values represent the average of ten treatments and four repetitions. Averages followed by the same letter, do not differ $(\mathrm{P}<0.05)$ by Tukey test. The average error-standard is presented in parenthesis.

Figure 1 - Quantity of live leaves (LL) in the main tiller of palisade grass in five weekly evaluations.
B. decumbens plants when they were submitted to a low water level in the soil ( $60 \%$ of the qFC) during all the establishment period, reducing by $24 \%$ the dry matter of the herbage mass compared to the control treatment ( $80 \%$ of the qFC).

Guenni et al. (2002) evaluated the biomass production of the Branchiaria ssp. It was observed for plants under water deficit during the vegetative period, a $23 \%$ reduction in the total dry matter of the B. brizantha plants (CIAT 6780 ) even after a seven-day period of rehydration.

Reduction of the root dry matter in $P$. maximum cv. Tobiatã plants, due to the water deficit, was also reported by Dias-Filho (1989).

The leaf:stem ratio (estimated by using data of Table 6) at the end of the experimental period, was similar to all the treatments with average values of $0.88 ; 0.95 ; 0.96$ and 1.05 , respectively for the control; $75 \mathrm{qFC}$; $50 \mathrm{qFC}$; and $25 \mathrm{qFC}$. This implies that the water levels in the soil influenced the development of the plants as a whole, without isolated effects on the specific morphological components.

Senescent matter yield showed the interaction effect between the water level and the development season $(\mathrm{P}=0.0141)$, when the lowest level of water in the soil provided the lowest production of senescent matter for all the development phases (Table 7). The literature confirms that, besides the plant natural development, the 
senescence is a process resulting from intense water deficit periods (Wright et al., 1983; Santos \& Carlesso, 1998; Taiz \& Zeiger, 2004) which is associated to the translocation of the nitrogen in the oldest leaves to the leaves in expansion and to the growth points (Taiz \& Zeiger, 2004).

In this study, the reduction in the senescence process in the tissues of plants submitted to the $25 q \mathrm{FC}$ treatment was observed (Table 7), due to the stationary growth of the plants in this treatment, which resulted in lower production, as well as the green tissues and the senescence process.

Andrade et al. (2005) observed the highest leaf senescene rate in Pennisetum purpureum Schum. cv. Napier plants, submitted to the resprouting under constant water supplement (irrigation) when compared to the non-irrigated plants, which was assigned by the authors, to the fastest development of the irrigated plants and the senescence process.

Most works using plants under water deficit are conducted with plants already established (Dias-Filho, 1989; Guenni et al., 2002; 2006; Mattos et al., 2005a, b), different from the conditions of this experiment, in which the plants were submitted to the water deficit from the sowing (establishment period). Other trials which consider the plants development during the establishment phase, under water deficit, must be conducted to characterize the production and the structural dynamic of the forage sward under this stress condition.

Table 6 - Dry matter yield according to the morphological component of the palisadegrass, according to the water level in the soil

\begin{tabular}{|c|c|c|c|c|}
\hline Water level ${ }^{1}$ & Leaf blade & Stem & Herbage mass & Root \\
\hline qFC (\%) & \multicolumn{4}{|c|}{ Dry matter (g/vase) } \\
\hline Control & $30.1(0.86) \mathrm{AB}$ & 34.2 (1.41)A & 64.4 (1.95)A & 50.4 (3.99)A \\
\hline 75 & $30.4(0.49) \mathrm{A}$ & $31.9(0.81) \mathrm{A}$ & 62.4 (1.13)A & $41.5(2.32) \mathrm{AB}$ \\
\hline 50 & $30.2(0.49) \mathrm{A}$ & $31.4(0.81) \mathrm{A}$ & 61.6 (1.13)A & $44.3(2.32) \mathrm{A}$ \\
\hline 25 & $27.7(0.49) \mathrm{B}$ & $26.4(0.81) \mathrm{B}$ & 54.1 (1.13)B & $35.0(2.32) \mathrm{B}$ \\
\hline
\end{tabular}

${ }^{1}$ Moisture (\%) of the soil regarding the field capacity (qFC) to restart the irrigation. The control values represent the average of four repetitions. The treatments values 75 ; 50 and 25 qFC represent the average of three development phases and four repetitions. Averages followed by the same letter in the column do not differ $(\mathrm{P}<0.05)$ by Tukey test. The average error-standard is presented in parenthesis.

Table 7 - Dry matter of palisadegrass senescent material, according to the water deficit introduction phase and the water level in the soil

\begin{tabular}{|c|c|c|c|c|}
\hline \multirow[t]{2}{*}{ Water deficit introduction 1} & \multicolumn{4}{|c|}{ Water level $^{2}$ (\%qFC) } \\
\hline & Control & 75 & 50 & 25 \\
\hline & \multicolumn{4}{|c|}{ Dry matter (g/vase) } \\
\hline Control & - & $6.1(0.35) \mathrm{AB}$ & $6.1(0.35) \mathrm{A}$ & 6.1 (0.35)A \\
\hline Sowing & $6.1(0.35) \mathrm{a}$ & $6.4(0.35) \mathrm{Aa}$ & $5.7(0.35) \mathrm{Aa}$ & $2.2(0.35) \mathrm{Bb}$ \\
\hline Germination & $6.1(0.35) \mathrm{a}$ & $4.5(0.35) \mathrm{Ba}$ & $6.0(0.35) \mathrm{Aa}$ & $2.3(0.35) \mathrm{Bb}$ \\
\hline Tillering & $6.1(0.35) \mathrm{a}$ & $6.6(0.35) \mathrm{Aa}$ & $6.2(0.35) \mathrm{Aa}$ & $3.4(0.35) \mathrm{Bb}$ \\
\hline
\end{tabular}

1 Sowing, germination and tillering = water deficit introduction period.

2 Moisture (\%) of the soil in relation to the field capacity (qFC) in order to restart the irrigation.

The values represent the average of four repetitions. The control treatment averages were put in all the lines and columns in order to make the comparisons between the values easier. Averages followed by the same letter, capital letter in the column and lower case letter in the line, do not differ $(\mathrm{P}<0.05)$ among themselves by Tukey test. The average error-standard is presented in parenthesis.

\section{Conclusions}

Water deficit imposed at the moment of the sowing and at the germination of the palisadegrass causes a delay in the tillering. Regardless to the development phase when the water deficit is imposed, during the plants establishment, there is a reduction in the development of the plants when the water level in the soil reaches $25 \%$ of moisture corresponding to the field capacity, causing reduction in the final production of leaves, stems and root dry matter. It should be avoided the overlapping of the sowing and the palisadegrass initial development with drought periods which can lead to the soil moisture levels to values close or lower than $25 \%$ of the field capacity. 


\section{References}

ANDRADE, A.C.; FONSECA, D.M.; LOPES, R.S. et al. Características morfogênicas e estruturais do capim-elefante “Napier” adubado e irrigado. Ciência Agrotécnica, v.29, p.150-159, 2005.

BERKOWITZ, G.A. Water and salt stress. In: RAGHAVENDRA, A.S. (Ed.). Photosynthesis: comprehensive reatise. Cambridge: Cambridge University, 1998. p.226-237.

CUNHA, F.F.; SOARES, A.A.; PEREIRA, O.G. et al. Características morfogênicas e perfilhamento do Panicum maximum jacq. cv. Tanzânia irrigado. Ciência Agrotécnica, v.31, p.628-635, 2007.

DIAS-FILHO, M.B. Respostas morfológicas de Panicum maximum Jacq. cv. Tobiatã ao estresse hídrico. Pesquisa Agropecuária Brasileira, v.24, p.893-898, 1989.

EMPRESA BRASILEIRA DE PESQUISA E AGROPECUÁRIA EMBRAPA. Centro Nacional de Pesquisa de Solos (Rio de Janeiro, RJ). Sistema brasileiro de classificação de solos. Brasília: Embrapa-SPI; Embrapa-CNPS, 1999. 412p.

GUENNI, O.; GIL, J.L.; BARUCH, Z. et al. Respuestas al déficit hídrico em especies forrajeras de Brachiaria (Trin.) griseb. (Poaceae). Interciencia, v.31, p.505-511, 2006.

GUENNI, O.; MARÍN, D.; BARUCH, Z. Responses to drought of five Brachiaria species. I. Biomass production, leaf growth, root distribution, water use and forage quality. Plant and Soil, v.243, p.229-241, 2002.

GOMIDE, J.A.; GOMIDE, C.A.M. Escolha da forrageira para a formação da pastagem. In: SIMPÓSIO SOBRE MANEJO DE PAStAGEnS, 24., 2007, Piracicaba. Anais... Piracicaba: FEALQ, 2007. p.472.

GOMIDE, C.A.M.; GOMIDE, J.A. Morfogênese de cultivares de Panicum maximum Jacq. Revista Brasileira de Zootecnia, v.29, p.341-348, 2000.

KRAMER, P.J. Plant and soil water relatioships. A modern synthesis. New Delhi: Mc-Graw-hill, 1995. 482p.

MALAVOLTA, E. Elementos da nutrição mineral de plantas. São Paulo: Ceres, 1980. 280p.
MATTOS, J.L.S.; GOMIDE, J.A.; HUAMAN, C.A.M. Crescimento de espécies de Brachiaria sob déficit hídrico e alagamento a campo. Revista Brasileira de Zootecnia, v.34, p.755-764, 2005 a.

MATTOS, J.L.S.; GOMIDE, J.A.; HUAMAN, C.A.M. Crescimento de espécies do gênero Brachiaria, sob déficit hídrico, em casa de vegetação. Revista Brasileira de Zootecnia, v.34, p.746-754, 2005b.

MELO, S.P.; KORNDÖRFER, G.H.; KORNDÖRFER, C.M. et al. Silicon accumulation and water deficit tolerance in Brachiaria grasses. Scientia Agricola, v.60, p.755-759, 2003.

NELSON, C.J.; ZARROUGH, K.M. Tiller density and tiller weight as yield determinants of vegetative swards. In: WRIGTH, C.E. (Ed.) Plant physiology and herbage production. Hurley: British Grassland Society, 1981. p.25-29.

NELDER, J.A.R.; WEDDERBURN, W.M. Generalized Linear Models. Journal of the Royal Statistical Society, v.135, p.370-384, 1972.

SANTOS, R.F.; CARLESSO, R. Déficit hídrico e os processos morfológico e fisiológico das plantas. Revista Brasileira de Engenharia Agrícola e Ambiental, v.2, p.287-294, 1998.

TAIZ, L.; ZEIGER, E. Fisiologia vegetal. Tradução de SANTARÉM, E.R. [et al.]. 3.ed. Porto Alegre: Artmed, 2004. 719p.

UNITED STATES. Department of Agriculture. Soil Survey Division. Soil Conservation Service. Soil Survey Staff. Soil taxonomy: a basic system of soil classification for making and interpreting soil surveys. 2.ed. Washington, 1999. 169p. (Agriculture Handbook, 436).

WRIGHT, G.C.; SMITH, R.G.; MCWILLIAM, J.R. differences between two grain sorghum genotypes in adaptation to drought stress. I. Crop growth rate and yield response. Australian Journal of Agricultural Research, v.34, p.615-626, 1983.

ZIMMER, A.H.; EUCLIDES, V.P.B. Importância das pastagens para o futuro da pecuária de corte no Brasil. In: SIMPÓSIO DE FORRAGICULTURA E PASTAGEM, 1., 2000, Lavras. Anais... Lavras: Universidade Federal de Lavras, 2000. p.1-49. 